\title{
A CAIXA, OS CUBOS E A AURA DO OBJETO ARTÍSTICO
}

Milena Guerson

Mestranda em Teoria da Literatura do Programa de Pós-Graduação em Estudos Literários /

UFMG

\begin{abstract}
RESUMO
Considerando o pensamento de Didi-Huberman, elabora-se um “grupamento/percurso” de obras de Artes Visuais, elencadas sob a menção à forma quadrangular e/ou cúbica. Destaca-se a herança de Marcel Duchamp para a estrutura da arte pós-moderna e contemporânea, o que é possível identificar pelas frequentes obras que abordam poéticas da memória.
\end{abstract}

\section{PALAVRAS-CHAVE}

Duchamp, imagem, memória

No início do livro $O$ que vemos, o que nos olha, a partir da aplicação de ideias de Merleau-Ponty em uma passagem do Ulisses, de Joyce, Didi-Huberman retoma questões sobre o ato de ver em arte. Utilizando o túmulo como ícone e influenciado por teorias psicológicas da reação diante da morte, desvenda para a História da Arte patamares entre a crença e a materialidade, imbricados no ato de ver. Ressalta a ideia de corpos, ou objetos, para além da propriedade básica de sua visibilidade mesma, tendo-os como "volumes dotados de vazios”, de reentrâncias; imagens ambivalentes que nos inquietam, nos interrogam, e de onde surge uma questão central: “(...): quando vemos o que está diante de nós, por que uma outra coisa sempre nos olha, impondo um em, um dentro?"1

Podemos vislumbrar que essa vontade de olhar o que há além dos objetos materiais liga-se ao anseio humano da busca por sua origem. A crença, parâmetro que permeia a subjetividade, é o que nos permite revestir com uma "aura” os objetos artísticos. Dessa maneira, podemos nos perguntar, como espectadores, o que há além de uma pintura, de uma escultura, e de um livro? Há, sem dúvida, experiência de vida, subjetividade e memória:

\footnotetext{
${ }^{1}$ DIDI-HUBERMAN. O que vemos, o que nos olha, p. 30, grifos do autor.
} 
(...) dar forma ao trabalho visual que deveria ser o nosso quando pousamos os olhos sobre o mar, sobre alguém que morre ou sobre uma obra de arte. Abramos os olhos para experimentar o que não vemos, o que não mais veremos - ou melhor, para experimentar que o que não vemos com toda a evidência (a evidência visível) não obstante nos olha como uma obra (uma obra visual) de perda. Sem dúvida, a experiência familiar do que vemos parece na maioria das vezes dar ensejo a um ter: ao ver alguma coisa, temos em geral a impressão de ganhar alguma coisa. Mas a modalidade do visível torna-se inelutável - ou seja, votada a uma questão de ser - quando ver é sentir que algo inelutavelmente nos escapa, isto é: quando ver é perder. Tudo está aí. ${ }^{2}$

Ao olhar algo, ganhamos aquela imagem, principalmente quando tomamos, em nosso arquivo de experiências, a imagem como conhecida; certificamos a imagem em nós. Quando não conhecemos o que vemos, estranhamos até formarmos a imagem, até nos acostumarmos a vê-la. Contudo, em vez de simples identificação, a visualidade, por vezes, nos proporciona certo alheamento, pela percepção de um outro apartado de nós; uma presença visível que ocasiona simultaneamente consubstanciação e deslocamento. Então nos voltamos para a questão do ser, olhamos para dentro de nós e nos refletimos no objeto:

Eis por que o túmulo, quando o vejo, me olha até o âmago - e nesse ponto, aliás, ele vem perturbar minha capacidade de vê-lo simplesmente, serenamente - na medida mesmo em que me mostra que perdi esse corpo que ele recolhe em seu fundo. Ele me olha também, é claro, porque impõe em mim a imagem impossível de ver daquilo que me fará o igual e o semelhante desse corpo em meu próprio destino futuro de corpo que em breve se esvaziará, jazerá e desaparecerá num volume mais ou menos parecido. (...). É a angústia de olhar o fundo - o lugar - do que me olha, a angústia de ser lançado à questão de saber (na verdade de não saber) o que vem a ser meu próprio corpo, entre sua capacidade de fazer volume e sua capacidade de se oferecer ao vazio, de se abrir.

Que fazer diante disso? Que fazer nessa cisão? Poderemos soçobrar, eu diria, na lucidez, supondo que a atitude lúcida, no caso, se chame melancolia. Poderemos, ao contrário, tentar tapar os buracos, suturar a angústia que se abre em nós diante do túmulo, e por isso mesmo nos abre em dois. Ora, suturar a angústia não consiste senão em recalcar, ou seja, acreditar preencher o vazio pondo cada termo da cisão num espaço fechado, limpo e bem guardado pela razão - uma razão miserável, convém dizer. ${ }^{3}$

Quando racionalizamos o efeito de uma perda, estamos apagando as premências de sonhos, de fantasias e esperanças; estamos “apagando” as ânsias imaginárias que poderiam surgir em nossa mente ou no sentimento. A imagética da pintura, do Renascimento até o Impressionismo, é constituída por ânsias imaginárias, pois há o figurativo a ser visto, há lugares reais que são relidos em tinta sobre o suporte, em imagens que se mostram para nós

\footnotetext{
${ }^{2}$ DIDI-HUBERMAN. O que vemos, o que nos olha, p. 34, grifos do autor.

${ }^{3}$ DIDI-HUBERMAN. O que vemos, o que nos olha, p. 38, grifos do autor.
} 
como novos mundos a serem admirados, almejados ou sonhados. Em movimentos como o Simbolismo, o Surrealismo e o Realismo Fantástico, a ânsia imaginária presente na pintura pode ser experienciada em seu auge. Com o Abstracionismo, entretanto, essa ânsia imaginária se perde, devido à derrocada figurativa, em prol da especificidade das formas - uma espécie de racionalização. Transportando, então, a questão da perda no ato de ver, para a perda da referência imagética, ocorrida gradualmente nas transformações do campo da Teoria Artística, nos remetemos a Marcel Duchamp, que se dizia cansado do racionalismo que vigorava na arte, mas que, entretanto, através de sua influência para a perda da referência imagética e fantástica da pintura, ocasiona que esta se torne, em certa medida, ainda mais racional.

A partir da obra duchampiana, Grande vidro, conjugada com a Caixa verde, vemos a destituição do suporte velado da tela, ficando evidenciada a transparência do vidro, que nos incita a olhar através da imagem pintada em sua superfície. E essa imagem transparente está extremamente conceituada e explicada nesse além, que é a Caixa, onde constam escritos e esboços que constituem o planejamento da obra. Mas dizemos isso para chegar até a questão fundamental: por que tanto projeto para concretizar uma obra? Talvez porque a pintura sobre vidro, em si, não seja a peça fundamental, mas sim a Caixa. A Caixa verde, na verdade, é um livro diferenciado, um livro de artista; livro caixa, caixa livro que nos incita para a questão do guardar. Nas caixas guardamos coisas para que não se percam; guardamos aquilo que temos intenção de proteger e de perpetuar. Um armário é diferente de uma vitrine, a Caixa verde é um armário, o Grande vidro é uma vitrine.

Se exibimos um vidro, não temos cautela em relação a ele, sabemos que o vidro corre o risco de se quebrar, como de fato aconteceu com o Grande vidro de Duchamp. Ao contrário, quando guardamos esboços e escritos dentro de uma caixa, o que estamos querendo dizer? O que a atitude de Duchamp ao efetuar a Caixa verde acabou dizendo para nós? Que se quebre o suporte, que se quebre a imagem, mas que se perpetue o registro do conceito; que se perpetuem as ideias originárias. Se a idéia é o que deve permanecer, lembramos o desnível existente entre a ideia e a materialidade, entre conceito e fazer, pois a materialidade é frágil e as ideias, para que também não se tornem frágeis, e para que não se percam na latência de existirem, ante a inconstância da memória, precisam ser guardadas; seja em caixas, seja em livros, seja da forma que melhor convier. Mas guardá-las é também materializá-las, fragilizálas, no que incorremos em um inevitável paradoxo.

O fato é que após a atuação de Duchamp, através dos ready-made, com a Caixa verde e, enfim, no conjunto de sua obra, novas formas de construção artística foram disseminadas. 
Principalmente construções que passam a dialogar com o luto, com o vazio, com o invisível, pois se perdeu a importância da técnica e da referência visual em arte - uma perda imagética:

(...) cada coisa a ver, por mais exposta, por mais neutra de aparência que seja, torna-se inelutável quando uma perda a suporta - ainda que pelo viés de uma simples associação de idéias, mas constrangedora, ou de um jogo de linguagem -, e desse ponto nos olha, nos concerne, nos persegue. (...) de um simples plano ótico, que vemos, uma potência visual que nos olha na medida mesmo em que põe em ação o jogo anadiômeno, rítmico, da superfície e do fundo, do fluxo e do refluxo, do avanço e do recuo, do aparecimento e do desaparecimento. ${ }^{4}$

Uma caixa nos remete a um cubo, que nos remete a um túmulo. Segundo DidiHuberman $^{5}$ (1998), quando olhamos um túmulo e nos atemos ao que é visto, ao volume externo do túmulo, negamos o cheio no sentido de não admitir o corpo a ocupar o espaço dentro do túmulo, e também negamos o vazio, no sentido de buscar nos atermos à forma externa do túmulo, para não admitir o espaço contido dentro da forma, para não deparar com o corpo também esvaziado. Esse exemplo é o da verdade rasa, "um exercício da tautologia”, quando aplicamos a recusa da "latência do objeto", ao desfazer do que está “jacente”, e dessa maneira, não há temporalidade nem memória no objeto. Temos uma vitória do olhar; reter-se no simples e presencial volume do objeto, essa é a visão que pede o Minimalismo. ${ }^{6}$

Terá feito tudo, esse homem da tautologia, para recusar as latências do objeto ao afirmar como um triunfo a identidade manifesta - minimal, tautológica - desse objeto mesmo: "Esse objeto que vejo é aquilo que vejo, um ponto, nada mais”. Terá assim feito tudo para recusar a temporalidade do objeto, o trabalho do tempo ou da metamorfose no objeto, o trabalho da memória - ou da obsessão - no olhar. Logo, terá feito tudo para recusar a aura do objeto, ao ostentar um modo de indiferença quanto ao que está justamente por baixo, escondido, presente, jacente. ${ }^{7}$

Para Didi-Huberman, o "homem da tautologia” é Donald Judd, ao abordar a necessidade de se produzir um objeto específico, onde prepondera o todo em detrimento da parte - tal como uma configuração gestaltica -, cuja percepção primeira é indecomponível.

Seria preciso, segundo Judd, fabricar um objeto que se apresentasse (e se representasse) apenas por sua mera volumetria de objeto - um paralelepípedo, por exemplo -, um objeto que não inventasse nem tempo nem espaço além dele mesmo. (...): eliminar todo detalhe para impor objetos

\footnotetext{
${ }^{4}$ DIDI-HUBERMAN. O que vemos, o que nos olha, p. 33.

${ }^{5}$ DIDI-HUBERMAN. O que vemos, o que nos olha.

${ }^{6}$ DIDI-HUBERMAN. O que vemos, o que nos olha, p. 39.

${ }^{7}$ DIDI-HUBERMAN. O que vemos, o que nos olha, p. 39.
} 
compreendidos como totalidades indivisíveis, indecomponíveis. "Todos sem partes", objetos qualificados por essa razão de "não relacionais".

Mas os cubos minimalistas demonstram, porém, o luto estabelecido ante a visualidade, pois reter as imagens na especificidade da forma perfeita, num ícone geométrico que não visa dizer nada além dele, é uma forma de velar a imagética perdida. Um cubo, assim como um túmulo, assim como uma caixa, visa apenas tanger o espaço e resguardar o vazio ou o cheio em si contido. E não deve haver detalhes, pois estes nos desviam a atenção, tal como DidiHubermam ressalta sobre os ornamentos de um túmulo, que podem funcionar como recursos para nos distrair da angústia por ele gerada, ou florear, ornamentar uma situação de dor.

O autor em pauta trata sobre outro artista minimal, Tony Smith, o qual atribui o título Die a uma de suas obras, que é nada menos do que um cubo preto em dimensões perfeitas. E Smith esclarece que a palavra Die, em inglês, pode nos remeter tanto ao pronome pessoal “eu”, quanto à palavra "olho”, e que é o infinitivo, também o imperativo, do verbo "morrer”. Além disso, é o singular de dice, dados de jogar, qualidade que “fornece uma descrição nominal elementar, sem equívoco, do objeto: um grande dado preto, simples, mas poderosamente mortífero." ${ }^{9}$ Tony Smith, ao intitular sua obra, expandiu interpretações para além da forma, diferente de Judd, que deixa sua obra sem título. Enquanto Judd apresenta o luto visual do Minimalismo, ao ressaltar a especificidade do volume, deixando o cubo sem nome, Smith certifica o luto visual ao aplicar o título Die.

(...) a mais simples imagem nunca é simples, (...). O que vemos é o que vemos. Por mais minimal que seja, é uma imagem dialética: portadora de uma latência e de uma energética. (...). O cubo de Tony Smith, apesar de seu formalismo extremo - ou melhor, por causa da maneira como seu formalismo se dá a ver, se apresenta -, frustra de antemão uma análise formalista que se considere como pura definição das “especificidades” do objeto. Mas frustra igualmente uma análise iconográfica que quisesse considerá-la a todo custo como "símbolo" ou alegoria no sentido trivial desses termos (ou seja no sentido dos manuais de iconografia). Diante dele, nosso ver é inquietado. Mas de que maneira um simples cubo pode chegar a inquietar nosso ver? ${ }^{10}$

Um cubo nos inquieta ao surgir no limiar do espaço. Seres humanos que somos, o simples fato de uma imagem ou de um objeto se apresentar diante de nós, torna-se um convite à reflexão. Acima de quaisquer esforços para prover o fanar ontogenético, este ainda

\footnotetext{
${ }^{8}$ DIDI-HUBERMAN. O que vemos, o que nos olha, p. 53, grifos do autor.

${ }^{9}$ DIDI-HUBERMAN. O que vemos, o que nos olha, p. 93-95, grifos do autor.

${ }^{10}$ DIDI-HUBERMAN. O que vemos, o que nos olha, p. 95, grifos do autor.
} 
prevalecerá, pois somos naturalmente "homens da crença”, e quando visamos ser "homens da tautologia”, ainda sim estamos a crer no substrato tautológico, visual, tátil.

Didi-Huberman também cita Ad Reinhardt, cujas obras em pintura tomamos como exemplo de outro exercício do luto pictórico; é quando um cubo negro se dissolve em uma tela. Diferente do “cubo" em perspectiva renascentista, diferente da multiplicidade de focos dos cubistas, as 120 telas negras de Reinhardt, com suas superfícies maquinalmente pintadas, não querem exibir sua superfície ao expectador, mas, sim, demonstrar conjuntamente a repetição que subverte os anseios pictóricos tradicionais. Apregoa Reinhardt, baseado em uma estrutura lógica: "Só há uma coisa a dizer acerca da arte, é que ela é uma coisa. A arte é a arte-como-arte (art-as-art), e o resto é o resto. A arte-como-arte é apenas arte. A arte não é o que não é arte.”11

Perpassando, então, o conceito da repetição, temos na Pop Art, principalmente na figura de Warhol, uma nova forma de luto, que ocorre pela banalização da imagem. Se nos cubos minimalistas e nas telas de Reinhardt vemos imagens de menos, em diversas obras de Warhol vemos imagens demais, tantas imagens que acabam nos direcionando a refletir sobre a banalidade imposta pela veiculação midiática; a figuração em arte é retomada e descaracterizada pelo excesso. Warhol, através da utilização da serigrafia, para viabilizar as reproduções, e apregoando o caráter figurativo das imagens, ao promover obras ligadas à publicidade e aos costumes sociais americanos do pós-guerra, consagrou-se como artista pop e como precursor direto da arte conceitual, a qual aparecerá em sua plenitude nos anos 1970.

Warhol introduziu em suas obras a repetição como discurso: começou em 1962, pintando a óleo 32 telas com latas de sopa comuns, mas viu que, com a serigrafia, era muito mais fácil, pois já não tinha de repetir manualmente o motivo. (...), estava usando a facilidade como imagem e como discurso e, portanto, a leitura fácil não era mais do que aparência. Dizia: "a idéia de América é tão maravilhosa porque, quanto mais igual algo é, mais americano é”. E, com essa idéia aparentemente simples, dotava sua obra de uma mensagem do tipo sociológico, sem renunciar à ambigüidade da qual tantas vezes se orgulhou, pois foi muito hábil na utilização do duplo sentido. A repetição como conceito de igualdade está ligada ao efeito homogeneizador da democracia, mas, em outro sentido, está também ligada ao poder dos meios de comunicação e, em especial, o mais atual naqueles anos, a televisão, que, por seu grande poder de difusão, introduziu importantes mudanças socioculturais nas formas de pensar e no comportamento. ${ }^{12}$

\footnotetext{
${ }^{11}$ Reinhardt citado por DIDI-HUBERMAN. O que vemos, o que nos olha, p. 194.

${ }^{12}$ PERERA RODRÍGUES. Warhol, p. 49.
} 
Se quando olhamos Duchamp, em sua suposta ausência de subjetividade, associamos ao mesmo uma atitude maquinal, certificamos essa atitude quando, herdeiro de Duchamp, Warhol chega a afirmar: “A razão pela qual pinto dessa maneira é porque quero ser uma máquina: quero fazer tudo o que faço, como uma máquina.” Essa é a frase que retoma Celant, ao explicitar que Warhol "marca o fim de uma atitude de veneração da história da arte e de sua proposta metafísico-teológica, que sempre gerou decisões carregadas de utopias e de desilusões”. ${ }^{13}$ Não sabemos, porém, se marca o fim ou um novo começo, quando uma caixa nos remete a um cubo, que nos remete a um túmulo, que nos remete a uma cápsula. Quando voltamos o olhar para As cápsulas do tempo, de Warhol, vemos ressaltada a necessidade de guardar referências, colecionar objetos, mantê-los longe do desaparecimento. Diferentemente do puro caráter da banalização, nessa obra perpetuação e banalização se confrontam, pois se guarda para não perder, ante a rapidez da passagem do tempo.

Certifica Adorno, contemporâneo de Warhol, sobre a necessidade e o sentimento da memória na época:

No ruidoso tique-taque do relógio percebe-se o escárnio dos anos-luz em relação à extensão da existência humana. As horas, que, como os segundos, já se passaram antes mesmo de serem apreendidas pelo sentido interno, arrastando-o consigo em sua queda, anunciam-lhe que ele, assim como tudo o que é memória, está consagrado ao esquecimento na noite cósmica. Disso as pessoas não podem deixar de se dar conta nos dias de hoje. Nesse estado de completa impotência, o indivíduo percebe o tempo que lhe resta para viver como o quarto de hora concedido antes da execução. ${ }^{14}$

O luto e a consequente necessidade da memória na arte pós-moderna passam a ocorrer, em grande medida, como reflexos da atuação duchampiana no final do século 19, e como heranças sociais do niilismo e do pensamento nietzschiano. Certamente essas não foram as únicas influências, o que não as exime de se configurarem em fatores relevantes. "Duchamp é um niilista que entendeu profundamente a sua (nossa) época. Sem ideologia ou moral, descrente dos grandes gestos ou das grandes causas, sua estética foi essencialmente ética.”15 Não a ética ilibada, à qual popularmente se costuma referir, mas considerando que, segundo Matos, “a palavra ethos aparece pela primeira vez em Homero, na Ilíada, significando toca, caverna, morada”, ${ }^{16}$ Duchamp certifica sua ética ao incorporar sua atitude niilista, ao se

\footnotetext{
${ }^{13}$ Celant citado por PERERA RODRÍGUES. Warhol, p. 93.

${ }^{14}$ ADORNO. Minima moralia, p. 145.

15 OSÓRIO. Duchamp: a crise da Arte. Disponível em: $<$ http://www.niteroiartes.com.br/cursos/laeca/modulos2.html>. Acesso em: 18 out. 2008.

${ }^{16}$ MATOS. Ética e comunicação: o problema do visível, p. 52.
} 
dedicar por inteiro à causa artística a que se propôs defender. O que passa a caber aos artistas, a partir de então, é manifestarem o luto dos meios pictóricos e/ou defenderem a comunhão com o ontológico, promovendo uma arte que remonte a ética em seu teor originário. Uma arte passível de resgatar unânimes florescências em sua potencialidade, recompor os pássaros nos inigualáveis voos, metáforas de imagens comuns que nos dizem, enfim, de uma arte passível de retirar a simples ideia de bem-estar do substrato movediço em que pode se encontrar. E tal como em rituais primitivos, relidos tecnicamente, nas obras de arte continuou-se a ouvir o lamento da perda.

Antes de referir-se ao caráter ético e à virtude, ethos é pertencimento numinoso, a partir do qual construir e habitar são tarefas que participam do sagrado, da indivisão antiga entre os homens, a natureza e os deuses. Na mais modesta casa, o homem imita a obra do deus, "cosmizando" o caos, santificando seu pequeno cosmos, fazendo-o semelhante ao divino. Permanecendo em um lugar determinado e determinável, a maneira de habitar é criação de valores, é ethos pelo qual a perfeição dos deuses prolonga-se e manifesta-se na ordem e na beleza do universo. ${ }^{17}$

O sublime na arte, na face que deriva da ontogenia, geralmente é legitimado, nos dias de hoje, com atitudes de perpetuação que façam ressaltar, por entre a miscigenação dos processos artísticos, a individualidade do artista, manifestada através do diferencial técnico, o que exige a mescla das atitudes poéticas com a perspicácia na construção. Jacques Rancière defende que ocorreu uma verdadeira revolução estética na contemporaneidade, e afirma:

Passar dos grandes acontecimentos e personagens à vida dos anônimos, identificar os sintomas de uma época, sociedade ou civilização nos detalhes ínfimos da vida ordinária, explicar a superfície pelas camadas subterrâneas e reconstituir mundos a partir de seus vestígios (...). ${ }^{18}$

Uma caixa nos remete a um cubo, que nos remete a um túmulo, que nos remete a uma cápsula, que nos remete a um bloco. Vemos, então, com ressonâncias na pauta da Arte Contemporânea, as obras de Rachel Whiteread, artista que visa materializar, preencher o vazio existente nos objetos, dar corpo ao “encavalgamento” existente nos objetos.

“Precisamos nos habituar”, escreve Merleau-Ponty, “a pensar que todo
visível é talhado no tangível, todo ser tátil é prometido de certo modo à
visibilidade, e que há invasão, encavalgamento, não apenas entre o tocado e
quem toca, mas também entre o tangível e o visível que está incrustado
nele”. Como se o ato de ver acabasse sempre pela experimentação tátil de

\footnotetext{
${ }^{17}$ MATOS. Ética e comunicação: o problema do visível, p. 52.

${ }^{18}$ RANCIÈRE. A partilha do sensível: estética e política, p. 49.
} 
um obstáculo erguido diante de nós, obstáculo talvez perfurado, feito de vazios. ${ }^{19}$

As esculturas de Whiteread são como jazigos onipotentes, que não nos incitam ao vazio da perda, mas é onde ganhamos o destaque da visualidade que não alcançaríamos - é uma forma de fomentação da memória. Alguém que visa materializar o vazio, intenta perpetuar o que seria uma ausência, se esta não viesse à tona. Afirma a artista: "Pareço-me contigo ao transformar-me, ao ser a tua gravação. Tu és exatamente aquilo que se perdeu desde que passaste a ser o molde em que eu me tornei." ${ }^{20}$ Habitamos o interior de uma casa, mas não percebemos concretamente o espaço pelo qual transitamos, pelo qual flutuamos. Whiteread elabora espécies de negativos do espaço, negativos concretos, monumentais, que se colocam às nossas vistas, para que se desperte as percepções, ante o que não vemos. $\mathrm{O}$ trabalho de Whiteread "é ainda sublinhado pela mundanidade relacionada com o corpo, a natureza humana das várias funções possuídas pelos objetos que ela molda - o vestir, o dormir, o lavar ou o habitar.,21

Ou seja, coisas a ver de longe e a tocar de perto, coisas que se quer ou não se pode acariciar. Obstáculos, mas também coisas de onde sair e onde reentrar. Ou seja, volumes dotados de vazios. Precisemos ainda a questão: o que seria portanto um volume - um volume, um corpo já - que mostrasse, no sentido quase wittgensteiniano do termo, a perda de um corpo? O que é um volume portador, mostrador de vazio? Como mostrar um vazio? E como fazer desse ato uma forma - uma forma que nos olha? ${ }^{22}$

Uma caixa nos remete a um cubo, que nos remete a um túmulo, que nos remete a uma cápsula, que nos remete a um bloco, que nos remete a um livro. Outra obra de Whiteread é o Memorial às vítimas do Holocausto, onde temos a referência a uma biblioteca, na qual os livros se apresentam unidos em blocos, não os blocos de notas escritas, rascunhadas, que nos lembraria a feitura de um livro comum. Mas temos blocos de "borracha natural e fibras de vidro,” blocos impossíveis de serem abertos, livros impossíveis de serem lidos, remontando em seu conjunto a memória de um acontecimento histórico, e especificamente o "fato de a sobrevivência do Judaísmo durante a sua diáspora de milhares de anos não ter despendido de nenhuns livros ou escritos”. 23

\footnotetext{
${ }^{19}$ DIDI-HUBERMAN. O que vemos, o que nos olha, p. 31.

${ }^{20}$ WHITEREAD citado por STANGE, Rachel Whiteread, p. 182.

${ }^{21}$ STANGE. Rachel Whiteread, p. 185.

${ }^{22}$ DIDI-HUBERMAN. O que vemos, o que nos olha, p. 35.

${ }^{23}$ STANGE. Rachel Whiteread, p. 185.
} 
Quando olhamos um bloco no espaço, a tanger nossa subjetividade, em verdade o bloco monumental é memória que visa nos tocar. Sejam os blocos de Whiteread, sejam blocos de notas, que originam livros, percebemos que as obras, tanto de Artes Visuais quanto de Literatura, só nos tocam porque somos "homens da crença”, sensíveis à interpelação que nos é apresentada pelas obras de arte e, de modo especial, pelas obras que abordam poéticas da memória.

Seja como for, o homem da crença verá sempre alguma outra coisa além do que se vê, quando se encontra face a face com uma tumba. Uma grande construção fantasmática e consoladora faz abrir seu olhar, como se abriria a cauda de um pavão, para liberar o leque de um mundo estético (sublime ou temível) e também temporal (de esperança ou de temor). (...) Prefiguração, retorno, julgamento, teleologia: um tempo reinventa-se aí, diante da tumba, na medida mesmo em que é o lugar real que é rejeitado com pavor - a materialidade do jazigo e sua função de caixa que encerra, que opera a perda de um ser, de um corpo doravante ocupado em se desfazer. O homem da crença prefere esvaziar os túmulos de suas carnes putrescentes, desesperadamente informes, para enchê-los de imagens corporais sublimes, depuradas, feitas para confortar e informar - ou seja, fixar - nossas memórias, nossos temores e nossos desejos. ${ }^{24}$

Mundos são inventados e reinventados em livros, livros são inventados e reinventados enquanto objetos. Os livros de artista, que têm vigorado nas Artes Visuais da contemporaneidade, tal como caixas, como túmulos, como monumentos interrogativos, querem nos antepor novas formas de leitura. O artista contemporâneo se rendeu às interrogações que as páginas dos livros colocam por diante: como essas páginas podem ser relidas? A plasticidade é, sem dúvida, ressaltada, mas, por que a necessidade dessas releituras plásticas sobre as páginas dos livros e sobre o objeto-livro em si? Talvez porque sejam itens fortemente representativos da memória propriamente dita.

Livros existem para que a perpetuação se faça, desde as escrituras em placas de argila ou paredes de cavernas e templos, até o design tecnologicamente amparado da atualidade. Livros são feitos para veicular os mundos idealizados e materializados pelas pessoas, através dos códigos - as palavras e as línguas. E se livros são memória instituída e, ainda mais, universalmente reconhecidos, fatalmente seriam abordados com fervor na contemporaneidade em arte, haja vista a necessidade de fomentação da memória, ante a miscigenação das técnicas e do anonimato que pairam na produção artística atual. As páginas dos livros tornam-se palcos de técnicas plurais, constituintes de poéticas do tempo-espaço.

Conforme expõe Paulo Silveira, no livro A página violada, o

\footnotetext{
${ }^{24}$ DIDI-HUBERMAN. O que vemos, o que nos olha, p. 48.
} 
exercício de compreensão [desses livros-objeto] tem como eixo o problema plástico que a página oferece para a expressão de sentimentos de apreço às conformações consagradas, por um lado, ou de violação de seus princípios (cânones) pelo gesto reformador, transformador ou desconstrutor (....). ${ }^{25}$

Ainda conforme esse autor, os termos “ternura” e “injúria” são centrais onde há veneração à forma tradicional do livro, ou rompimento dessa tradição representativa, no que "as duas posições podem compartilhar a mesma obra, gerando tensão plástica na página e/ou no volume, ressalvada a possibilidade conceitual e temática da existência da não-página e do não-volume”. 26

E a memória aplicada aos livros de artista se torna ainda mais própria, quando os livros-objeto primam pela unicidade, ou seja, quando não podem ser reproduzidos. Se são únicos, pedem um público selecionado e estão, de certa forma, fadados ao anonimato. Existem por existirem, existem por perpetuar aquele que o empreendeu - são quase uma lápide que espera imóvel os que a visitam para recordar. Não se desesperam por se multiplicar pelo mundo e assim se tornam uma fenda na sociedade global.

A internet, a televisão, a fotografia, a imprensa, são meios de se multiplicar e popularizar o acesso à memória, mas as imagens são indiretas; podemos tocar nessas imagens, não conseguiremos atingir o objeto originário, não poderemos sentir com toda a potência o que fica entranhado no objeto mesmo. Para Benjamin, em suma, a aura se caracteriza pelo que um objeto carrega em si, ou seja, envolve seu passado, sua história, desde sua constituição; no que o cinema, principalmente, quebraria pela reprodutibilidade esse valor aurático. ${ }^{27}$ Para Didi-Huberman, a origem, entretanto, não é eidética, não nos diz sobre a essência, mas se configura em algo sempre inacabado; assim, em vez de começo fechado, temos modificação constante, ou seja, imagens dialético-críticas que sempre questionam sua maneira de ser e nossa maneira de ver. ${ }^{28}$

Então, pautados em Didi-Huberman, mesmo se um objeto originário perdeu-se, ou se é mantido museologicamente conservado, podemos considerar que os diversos meios que nos forneçam acesso à sua imagem, ainda assim, se tornam cheios da aura da perpetuação. Multiplicar é fomentar memória. E chegamos a pensar em relação à finitude das obras de arte: que obras foram feitas para durar? Que obras foram feitas para ser efêmeras? Que obras foram

\footnotetext{
${ }^{25}$ SILVEIRA. A página violada, p. 21.

${ }^{26}$ SILVEIRA. A página violada, p. 21.

${ }^{27}$ BENJAMIN. A obra de arte na era de sua reprodutibilidade técnica.

${ }^{28}$ DIDI-HUBERMAN. O que vemos, o que nos olha.
} 
feitas para se restaurar? Que obras foram feitas para ser ruína? E as que foram feitas para não chegar a ser, se descaracterizaram e acabaram sendo? Os Ready-made infestam museus, e as obras abordam, hoje, de maneira destacada, o intangível e o desaparecimento. Como herança duchampiana, há obras que querem cegar, para ressaltar a ideia.

Livros de artista são poemas encarnados, corpos visuais que se colocam às nossas vistas, a nos ofertar poesia materializada, em rituais sensíveis de imagem e palavra, quando uma caixa nos remete a um cubo, que nos remete a um túmulo, que nos remete a uma cápsula, que nos remete a um bloco, que nos remete a um livro e que nos remete a nós mesmos, morada que somos.

Diante de uma obra de arte, somos solicitados a considerar nosso interior e, por vezes, passamos da memória ao sonho; é quando temos a premência de “querer superar imaginariamente - tanto o que vemos quanto o que nos olha. O volume perde então sua evidência de granito, e o vazio perde igualmente seu poder inquietante (...)”29, pois buscamos "produzir um modelo fictício no qual tudo - volume e vazio, corpo e morte - poderia se reorganizar, subsistir, continuar a viver no interior de um grande sonho acordado.”30 O lugar onde se vive passa a ser

demasiado inquietante em significar algo de inelutável e de definitivo. Nada, nessa hipótese, será definitivo: a vida não estará mais aí, mas noutra parte, onde o corpo será sonhado como permanecendo belo e bem feito, cheio de substância e cheio de vida. ${ }^{31}$

Percebemos uma "vitória obsessional" da "linguagem sobre o olhar", onde se abre o descampado do invisível. “Aqui o que vemos (o triste volume) será eclipsado, ou melhor, relevado pela instância legiferante de um invisível a prever.”32

Adorno aborda o pensamento de Nietzsche sobre a perda do valor da verdade:

No fim das contas, a esperança - na medida em que se arranca da realidade ao negá-la - é a única forma na qual a verdade se manifesta. Sem esperança seria quase impossível pensar a idéia da verdade, e a inverdade capital é fazer passar por verdade a existência reconhecida como má, simplesmente porque ela foi reconhecida. ${ }^{33}$

\footnotetext{
${ }^{29}$ DIDI-HUBERMAN. O que vemos, o que nos olha, p. 40.

${ }^{30}$ DIDI-HUBERMAN. O que vemos, o que nos olha, p. 40.

${ }^{31}$ DIDI-HUBERMAN. O que vemos, o que nos olha, p. 40.

${ }^{32}$ DIDI-HUBERMAN. O que vemos, o que nos olha, p. 41.

${ }^{33}$ ADORNO. Minima moralia, p. 85.
} 
A esperança possui a característica de se "arrancar” da realidade e, logo, de instaurar nova visão, superando a catarse do meio. A esperança é o próprio meio viabilizador de mudança, pois promove o confrontamento com a realidade. Quando estagnamos tautologicamente ante o real, não deixamos preponderar nenhuma instância capaz de romper um possível estado de acomodação; alimentar a esperança, entretanto, gera perspectivas para o provimento de alterações.

A esperança é da ordem da crença, do sonho e da fantasia. "Quem não vê nem possui nenhuma outra coisa para amar, acaba amando muralhas de pedra e janelas com grades."34 Se não há incentivos para a esperança, nos atemos ao mal-estar social, pode-se dizer ao estado de horror, ante o qual, por exemplo, a veiculação de imagens midiáticas pode nos fazer acomodar, devido à banalização, que retira o aspecto crítico e dialético das imagens (cenários que já não nos inquietam). Quando se incentiva a esperança, porém, construímos possibilidades de mudança, que, arrancadas da utopia, tornam-se nova realidade. Com isso intentamos dizer que a arte possui necessariamente a função de ser fomentadora de esperança, em detrimento de ocasionar mal-estar. Não se deve temer ou julgar irrelevante a defesa de que a arte deve abranger o sonho e a fantasia, motores da esperança, quesitos básicos do “humano”. É a arte sonhadora que nos permite certificar a ética em seus parâmetros mesmos, reconstituindo moradas, legitimando a memória saudavelmente através das gerações. A aura não finda, mas se transmuta, e se certifica hoje em poéticas de arquivo, tecnológicas ou não, conforme o gosto de quem as empreende.

As obras de pensamento representam partes inteiras de uma vida e de toda uma existência construída de paradoxos, enganos e liberdade. É preciso gerações para recebê-las e interpretá-las (...). Uma vida examinada nas obras de cultura não pode ser regida pela temporalidade e pelos valores da mídia que impregnam a cultura e a educação. Todas as obras que se consideram universais no campo da cultura são o resultado de universos que, aos poucos, superando as leis do mundo comum e, sobretudo, a lógica do lucro, se foram consolidando. ${ }^{35}$

Para Seligmann-Silva, a "memória enquanto vis, ou seja, como força vital e construtora da identidade", difere da "memória como ars", que envolve um "procedimento mecânico de arquivamento e recuperação de informações”; vigoram assim dois polos sobre a memória, uma votada ao antropológico, outra votada à técnica. ${ }^{36} \mathrm{~A}$ reprodutibilidade não

\footnotetext{
${ }^{34}$ ADORNO. Minima moralia, p. 85.

${ }^{35}$ MATOS. Ética e comunicação: o problema do visível, p. 60.

${ }^{36}$ SELIGMANN-SILVA. A escritura da memória: mostrar palavras e narrar imagens, p. 99.
} 
destrói o humano, nem destrói a crença ou o tempo-espaço humanos. Uma tela de pintura tende ao quadrangular, uma fotografia tende ao quadrangular, as telas de cinema tendem ao quadrangular, um computador tende ao quadrangular, monitores, tal como televisores, eram cubos, hoje têm sofrido achatamento, e são quase novamente telas de pintura, apesar de super equipadas. E permanecemos assim, homens vitruvianos, tangenciando o que nos circunda ou circula, ante os enquadramentos do moderno ao contemporâneo.

\begin{abstract}
Considering the thought of Didi-Huberman, a "group/route" of works of visual arts is elaborated, listed under the mention of the quadrangular and/or cubic forms. Marcel Duchamp's heritage is highlighted in the context of postmodern and contemporary art, which is possible to identify by the frequent works that address the memory.
\end{abstract}

KEYWORDS

Duchamp, image, memory

\title{
REFERÊNCIAS
}

ADORNO, T. W. Minima moralia. Trad. Luiz E. Bicca. São Paulo: Ática, 1992.

ARCHER, M. Arte contemporânea: uma história concisa. Trad. Alexandre Krug e Valter Lellis Siqueira. São Paulo: Martins Fontes, 2001.

BENJAMIN, W. A obra de arte na era de sua reprodutibilidade técnica. In: . Magia e técnica, arte e política. Trad. Sérgio Paulo Rouanet. São Paulo: Brasiliense, 1996. p. 165-196. DIDI-HUBERMAN, G. O que vemos, o que nos olha. Trad. Paulo Neves. São Paulo: Ed. 34, 1998.

KRAUSS, R. Formas de Ready-made: Duchamp e Brancusi. In: . Caminhos da escultura moderna. Trad. Julio Fischer. São Paulo: Martins Fontes, 1998.

MATOS. O. C. F. Ética e comunicação: o problema do visível. Inter-Ação: Revista da Faculdade de educação da UFG, v. 28, n. 1, p. 51-56, jan./jun. 2003.

OSÓRIO, L. C. Duchamp - a crise da arte. Disponível em: <http://www.niteroiartes.com.br/cursos/laeca/modulos2.html>. Acesso em: 18 out. 2008.

PAZ, O. Marcel Duchamp ou o Castelo da Pureza. Trad. Sebastião Uchoa Leite. São Paulo: Perspectiva, 2002.

PERERA RODRÍGUEZ, M. P. Warhol. Trad. Mathias de Abreu Lima Filho. São Paulo: Girassol, 2002. 
RANCIÈRE, J. A partilha do sensível: estética e política. Trad. Mônica Costa Netto. São Paulo: Ed. 34. 2005.

SILVEIRA, P. A página violada. Porto Alegre: Ed. UFRGS, 2001.

SELIGMANN-SILVA, M. A escritura da memória: mostrar palavras e narrar imagens. Terceira Margem - Revista do Programa de Pós-Graduação em Ciência da Literatura UFRJ, v. 7, p. 91-107, 2002.

STANGE, R. Rachel Whiteread. In: GROSENICK, Uta (Org.). Mulheres artistas nos séculos XX e XXI. Trad. Carlos Sousa de Almeida. Köln: Taschen, 2003. p. 182-185. 